\title{
Determination of Dynamic Ocean Topography Using the Minimum Energy State
}

\author{
Peter C Chu \\ Naval Ocean Analysis and Prediction Laboratory, Department of Oceanography, Naval Postgraduate School, Monterey, USA
}

Copyright $(2018$ by authors, all rights reserved. Authors agree that this article remains permanently open access under the terms of the Creative Commons Attribution License 4.0 International License

\begin{abstract}
Geostrophic balance represents the minimum energy state in a linear system with conservation of potential vorticity. On the base of that, a minimum energy state (MES) method is proposed to determine dynamic topography $(\eta)$ and in turn the absolute geostrophic velocity from hydrographic data through finding $\eta$ to minimize a functional, $G\left(\eta_{x}, \eta_{y}\right)=\iint_{R}\left\{\left[H\left(\eta_{x}^{2}+\eta_{y}^{2}\right)+2 \eta_{x} C-2 \eta_{y} B\right] / f^{2}\right\} d x d y \rightarrow \min$
\end{abstract}

Numerical approach leads to a set of well-posed linear algebraic equations of $\eta$ at grid points. Feasibility and advantage of the MES method are illustrated using the three-dimensional $(T, S)$ data of the NOAA National Centers for Environmental Information (NCEI) World Ocean Atlas 2013 version 2 for the North Atlantic Ocean $\left(100^{\circ} \mathrm{W}-6^{\circ} \mathrm{W}, 7^{\circ} \mathrm{N}-72^{\circ} \mathrm{N}\right)$ on $1^{\circ} \times 1^{\circ}$ grids.

Keywords Absolute Geostrophic Currents, Basic Equation for Dynamic Ocean Topography, Conservation of Potential Vorticity, Dynamic Ocean Topography, Inverse Method, Minimum Energy State, P-vector Method, North Atlantic Ocean Circulation

\section{Introduction}

Determination of ocean general circulation from temperature $(T)$ and salinity $(S)$ observations using the thermal wind relation is a classical problem. In the Cartesian coordinates with $(x, y)$ in the horizontal and $z$ in the vertical coordinates, the horizontal and vertical velocities are represented by $(u, v)$ and $w$. As mentioned in [1], the quantities $T, S$ are relatively easy to measure, and in contrast to velocity observations, the climatological signal in the $(T, S)$ fields is less contaminated by energetic smaller-scale motions induced by eddies and waves. However, the hydrographic data only determine the baroclinic geostrophic currents (i.e., relative velocity between two depths). A reference velocity (i.e., velocity at reference depth $\left.z_{\text {ref }}\right)\left(u_{\text {ref }}, v_{\text {ref }}\right)$ still needs to be determined by the inverse methods locally and non-locally.

The local inverse methods use the hydrographic data nearby the water column such as the $\beta$-spiral method [2] [3], the Bernoulli method [4], and the P-vector method [5]-[10]. The non-local inverse methods use the hydrographic data for the whole area such as the box method [11,12]. It was pointed out in [13] that the $\beta$ -spiral method and the box method, no matter how different in appearance, are based on the same order of dynamical sophistication and differ from implicit assumptions about the scales of oceanic variability and different definitions of the smooth field to which the dynamical model pertains. No matter local-type or non-local-type, all the existing inverse methods estimate two parameters $\left(u_{\text {ref }}, v_{\text {ref }}\right)$ at deep depths, and not at the ocean surface.

If the ocean surface taken as the reference level, the problem can be changed from two parameter $\left(u_{\text {ref }}, v_{\text {ref }}\right)$ determination into one parameter [i.e., the dynamic topography $(\eta)$ ] determination since the geostrophic velocity $\left[\left(u_{g}(0), v_{g}(0)\right]\right.$ at the ocean surface is calculated by

$$
u_{g}(0)=-\frac{g}{f} \frac{\partial \eta}{\partial y}, \quad v_{g}(0)=\frac{g}{f} \frac{\partial \eta}{\partial x}
$$

and in turn the absolute geostrophic velocity at depth $z$ is calculated by

$$
\begin{aligned}
& u_{g}(z) \equiv u_{g}(0)+u_{B C}, \quad v_{g}(z) \equiv v_{g}(0)+v_{B C} \\
& u_{B C}=-\frac{g}{f \rho_{0}} \int_{z}^{0} \frac{\partial \hat{\rho}}{\partial y} d z^{\prime}, \quad v_{B C}=\frac{g}{f \rho_{0}} \int_{z}^{0} \frac{\partial \hat{\rho}}{\partial x} d z^{\prime}
\end{aligned}
$$

Here, $\hat{\rho}$ is the in-situ density; $\rho_{0}=1025 \mathrm{~kg} \mathrm{~m}^{-3}$ is the characteristic density; $g$ is the gravitational acceleration; $f$ is the Coriolis parameter; and the Boussinesq approximation is used.

On the base of geostrophic and hydrographic balances, and the conservation of the potential vorticity, the mechanical energy (kinetic and available potential energies) reaches minimum state as the ocean circulation 
takes the geostrophic velocity. With this minimum energy state, a new methodology has been developed to determine the dynamic topography $(\eta)$ and in turn the absolute geostrophic velocity from hydrographic data. The main objective of this study is to show the theoretical background and technical part of this method. The rest of paper is outlined as follows. Section 2 depicts the minimum energy state (MES). Section 3 presents the MES inverse method including basic principles, numerical approach, and well-posed linear algebraic equations. Section 4 shows an example. Section 5 gives the conclusions.

\section{Minimum Energy State}

\subsection{Conservation of Potential Vorticity}

Let the background fluid be motionless with the background density $(\bar{\rho})$ being horizontally uniform and vertically increasing with depth linearly

$$
\partial \bar{\rho} / \partial z \equiv-\rho_{0} N^{2} / g=\text { const },
$$

where $N$ is the buoyancy frequency. The pressure field for the motionless background fluid is given by

$$
\frac{\partial \bar{p}(z)}{\partial z}=-\bar{\rho}(z) g
$$

The density and pressure can be decomposed into background $(\bar{\rho}, \bar{p})$ and perturbation $(\rho, p)$

$$
\hat{\rho}=\bar{\rho}(z)+\rho, \quad \hat{p}=\bar{p}(\mathrm{z})+p .
$$

Eq.(4a) implies,

$$
\frac{\partial \hat{\rho}}{\partial x}=\frac{\partial \rho}{\partial x}, \quad \frac{\partial \hat{\rho}}{\partial y}=\frac{\partial \rho}{\partial y} .
$$

The linearized basic equations with the Boussinesq approximation are given by

$$
\begin{gathered}
\frac{\partial u}{\partial t}-f v=-\frac{1}{\rho_{0}} \frac{\partial p}{\partial x}, \\
\frac{\partial v}{\partial t}+f u=-\frac{1}{\rho_{0}} \frac{\partial p}{\partial y}, \\
\frac{\partial w}{\partial t}=-\frac{1}{\rho_{0}} \frac{\partial p}{\partial z}-\frac{\rho}{\rho_{0}} g, \\
\frac{\partial u}{\partial x}+\frac{\partial v}{\partial y}+\frac{\partial w}{\partial z}=0 \\
\frac{\partial \rho}{\partial t}-\frac{\rho_{0} N^{2}}{g} w=0 .
\end{gathered}
$$

where $\rho_{0}$ is the characteristic density. Conservation of potential vorticity $(q)$ can be derived from (6a)-(6e),

$$
\frac{\partial q}{\partial t}=0
$$

where

$$
q \equiv\left[f+\left(\frac{\partial v}{\partial x}-\frac{\partial u}{\partial y}\right)\right] \frac{\partial \hat{\rho}}{\partial z} \doteq f\left(-\frac{\rho_{0} N^{2}}{g}+\frac{\partial \rho}{\partial z}\right)-\frac{\rho_{0} N^{2}}{g}\left(\frac{\partial v}{\partial x}-\frac{\partial u}{\partial y}\right),
$$

is a linearized potential vorticity. Here, (4a) and (4c) are used.

\subsection{Extreme Energy State}

The mechanical energy (sum of the kinetic and available potential energy) per unit mass is defined by

$$
e=\frac{1}{2}\left(u^{2}+v^{2}+w^{2}\right)+\frac{g^{2}}{2 \rho_{0}^{2} N^{2}} \rho^{2} .
$$

The mechanical energy in a volume $\Omega$ is represented by

$$
E=\rho_{0} \iiint_{\Omega} e d \Omega .
$$

Incorporation of the potential vorticity conservation constraint (8) leads to the functional

$$
\mathcal{J}=\rho_{0} \iiint_{\Omega} J d \Omega
$$

where

$$
\begin{gathered}
J \equiv \frac{1}{2}\left(u^{2}+v^{2}+w^{2}\right)+\frac{g^{2}}{2 \rho_{0}^{2} N^{2}} \rho^{2}+ \\
+\lambda(x, y, z)\left[f\left(-\frac{\rho_{0} N^{2}}{g}+\frac{\partial \rho}{\partial z}\right)-\frac{\rho_{0} N^{2}}{g}\left(\frac{\partial v}{\partial x}-\frac{\partial u}{\partial y}\right)\right]
\end{gathered}
$$

and $\lambda(x, y, z)$ is the Lagrange multiplier, which is a function of space. If it were a constant, the integral would merely extremize energy subject to a given integral of potential vorticity, and rearrangement of potential vorticity would leave the integral unaltered. Extremization of the integral $\mathcal{J}$ leads to the three Euler-Lagrange equations,

$$
\begin{aligned}
& \frac{\partial J}{\partial \rho}-\frac{\partial}{\partial z} \frac{\partial J}{\partial \rho_{z}}=0, \\
& \frac{\partial J}{\partial u}-\frac{\partial}{\partial y} \frac{\partial J}{\partial u_{y}}=0, \\
& \frac{\partial J}{\partial v}-\frac{\partial}{\partial x} \frac{\partial J}{\partial v_{x}}=0 .
\end{aligned}
$$

Substitution of (12) into (13), (14a, b) leads to

$$
\begin{gathered}
\frac{g^{2}}{\rho_{0}^{2} N^{2}} \rho=f \frac{\partial \lambda}{\partial z}, \\
u=\frac{\rho_{0} N^{2}}{g} \frac{\partial \lambda}{\partial y}, \quad v=-\frac{\rho_{0} N^{2}}{g} \frac{\partial \lambda}{\partial x} .
\end{gathered}
$$

Differentiation of (16) with respect to $z$ and use of (15) leads to 


$$
\frac{\partial u}{\partial z}=\frac{g}{f \rho_{0}} \frac{\partial \rho}{\partial y}, \quad \frac{\partial v}{\partial z}=-\frac{g}{f \rho_{0}} \frac{\partial \rho}{\partial x}
$$

\section{MES Inverse Method}

\subsection{Basic Principle}

Since $E$ reaches the extreme state as the velocity takes the geostrophic velocity $\left(u_{g}, v_{g}\right)$ subject to a given potential vorticity. With the geostrophic and hydrographic balances, the large-scale the potential vorticity is calculated from the density field [5]. It can also be proved that $E$ takes minimum state. However, it is beyond the scope of this study since the new inverse method is only on the base of the extremization of $E$ (hereafter, the minimization is used instead of extremization) and the main objective here is to show the techniques. Substitution of (1)-(3) and (9) into (10) leads to

$$
\begin{aligned}
& E\left(\eta_{x}, \eta_{y}\right)=\frac{g^{2} \rho_{0}}{2} \iiint_{\Omega}\left[\left(-\eta_{y}+\frac{f u_{B C}}{g}\right)^{2} / f^{2}+\left(\eta_{x}+\frac{f v_{B C}}{g}\right)^{2} / f^{2}+\frac{\rho^{2}}{\rho_{0}^{2} N^{2}}\right] d \Omega \\
& =\frac{g^{2} \rho_{0}}{2} \iiint_{\Omega}\left[\eta_{x}^{2} / f^{2}+\eta_{y}^{2} / f^{2}+2 \eta_{x} \frac{v_{B C}}{f g}-2 \eta_{y} \frac{u_{B C}}{f g}\right] d \Omega \\
& +\frac{\rho_{0}}{2} \iiint_{\Omega}\left[u_{B C}^{2}+v_{B C}^{2}+\frac{g^{2} \rho^{2}}{\rho_{0}^{2} N^{2}}\right] d \Omega
\end{aligned}
$$

where $\eta_{x}=\partial \eta / \partial x, \quad \eta_{y}=\partial \eta / \partial y$. For a given density field, the second integration in (18) is given. The minimization is reached as

$$
G\left(\eta_{x}, \eta_{y}\right) \equiv \iiint_{\Omega}\left[\left(\eta_{x}^{2}+\eta_{y}^{2}+2 \eta_{x} \frac{f v_{B C}}{g}-2 \eta_{y} \frac{f u_{B C}}{g}\right) / f^{2}\right] d \Omega \rightarrow \min ,
$$

which is the MSE method to determine the mean dynamic topography $(\eta)$ from hydrographic data in $\left(u_{B C}, v_{B C}\right)$ [see (3)]. Substitution of the thermal wind relation (3) into (19) leads to

$$
G\left(\eta_{x}, \eta_{y}\right)=\iint_{R}\left\{\left[H\left(\eta_{x}^{2}+\eta_{y}^{2}\right)+2 \eta_{x} C-2 \eta_{y} B\right] / f^{2}\right\} d x d y \rightarrow \min ,
$$

where $H=H(x, y)$ is the depth of the water column, $R$ is the horizontal area of the water volume, and the parameters $(B$, C) are defined by

$$
\begin{gathered}
B(x, y) \equiv \int_{-H}^{0} \frac{f u_{B C}}{g} d z=-\frac{1}{\rho_{0}} \int_{-H}^{0} \int_{z}^{0} \frac{\partial \hat{\rho}}{\partial y} d z^{\prime} d z \\
C(x, y) \equiv \int_{-H}^{0} \frac{f v_{B C}}{g} d z=\frac{1}{\rho_{0}} \int_{-H}^{0} \int_{z}^{0} \frac{\partial \hat{\rho}}{\partial x} d z^{\prime} d z
\end{gathered}
$$

Use of the Euler-Lagrangian equation of the functional (20) leads to an elliptic partial differential equation for $\eta$,

$$
f^{2} \nabla\left[\left(H / f^{2}\right) \nabla \eta\right]=-F, \quad F \equiv\left(\frac{\partial C}{\partial x}-\frac{\partial B}{\partial y}\right) .
$$

\subsection{Numerical Approach}

Let the three axes $(x, y, z)$ be discretized into generalized (non-rectangular in horizontal) grid $\left(x_{i, j}, y_{i, j}, z_{k}\right)$ with cell sizes $\left(\Delta x_{i, j}, \Delta y_{i, j}, \Delta z_{k}\right)$,

$$
\begin{gathered}
\Delta x_{i, j}=\frac{1}{2}\left(x_{i+1, j}-x_{i, j}+x_{i+1, j+1}-x_{i, j+1}\right), \\
\Delta y_{i, j}=\frac{1}{2}\left(y_{i, j+1}-y_{i, j}+y_{i+1, j+1}-y_{i+1, j}\right) \\
\Delta z_{k}=z_{k}-z_{k+1}, \quad i=1,2, \ldots, I ; j=1,2, \ldots, J ; k=1,2, \ldots, K_{i, j}
\end{gathered}
$$

which reduces to

$$
\Delta x_{i, j}=\Delta x, \quad \Delta y_{i, j}=\Delta y
$$

for a uniform rectangular horizontal grid. The subscripts in $K_{i, j}$ in (23a) indicates non-uniform water depth in the region. In a staggered grid, the density $(\rho)$ is evaluated at the original grid point $(i, j, k)$. The absolute and baroclinic geostrophic velocities are evaluated at the center of the grid volume (Figure 1). The dynamic topography $(\eta)$ is at the original grid point $(i, j)$ at the surface $(k=1)$.

The functional $G$ in (20) is discretized by

$$
\begin{aligned}
& G=\sum_{i=1}^{I} \sum_{j=1}^{J} \varepsilon_{i, j}, \quad \varepsilon_{i, j}=\left[H_{i, j}\left(\eta_{x}^{2}+\eta_{y}^{2}\right)_{i, j}+:\right. \\
& \left.+2\left(\eta_{x}\right)_{i, j} C_{i, j}-2\left(\eta_{y}\right)_{i, j} B_{i, j}\right] \Delta x_{i, j} \Delta y_{i, j} / f_{i, j}^{2}
\end{aligned}
$$

with its element $\varepsilon_{i, j}$ represents the integrated value for the upright grid cell in Figure 2. The variable $\eta_{i, j}$ at each grid point $\left(x_{i, j}, y_{i, j}\right)$ connects to the four neighboring $\varepsilon_{i-1, j-1}, \varepsilon_{i-1, j}, \varepsilon_{i, j-1}, \varepsilon_{i, j}$. The variable $\varepsilon_{i, j}$ connects the four neighboring $\eta_{i, j}, \eta_{i, j+1}, \eta_{i+1, j}, \eta_{i+1, j+1}$. The discretized functional $G$ is represented by (see Appendix A),

$G=G\left(\eta_{1,1}, \eta_{1,2}, \ldots, \eta_{1, J}, \ldots, \eta_{2,1}, \eta_{2,2}, \ldots, \eta_{2, J}, \ldots, \eta_{I, 1}, \eta_{I, 2}, \ldots, \eta_{I, J}\right)$,

which has $L=(I \times J)$ unknowns.

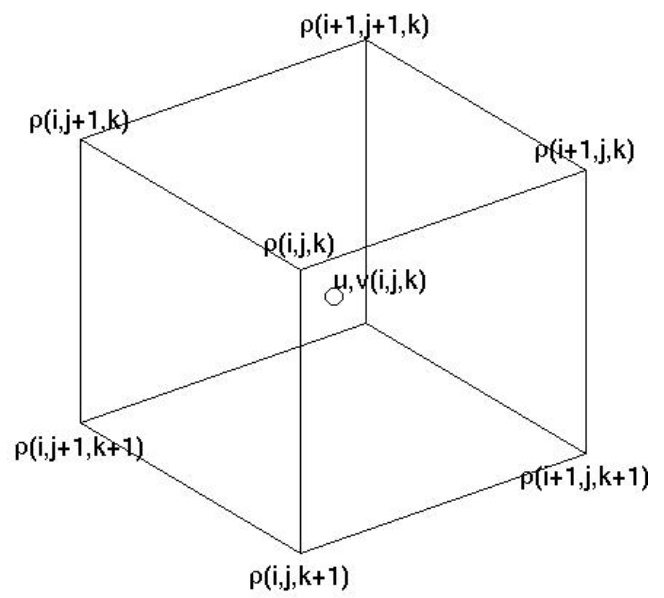

Figure 1. Staggered grid system with $(\rho, \eta)$ located at the regular grid points and the velocity $(u, v)$ evaluated at the center of grid volume 


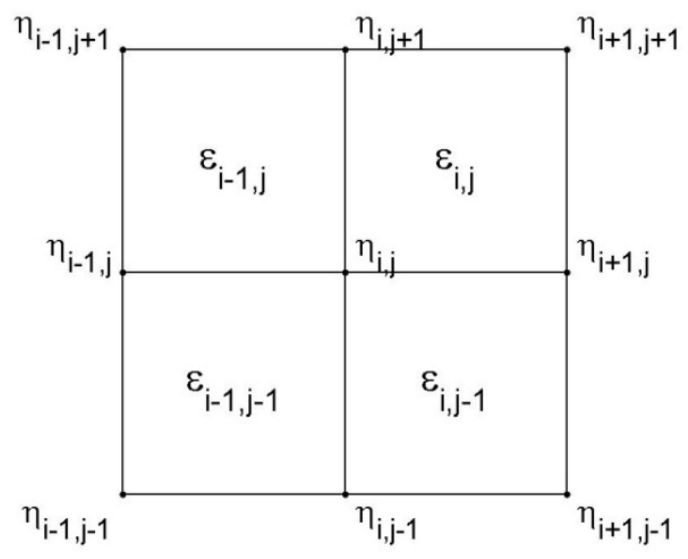

Figure 2. Dynamic topography $\eta$ located at the grid points and the associated $\varepsilon$ evaluated at the center of the grid cell

3.3. Well-Posed Linear System
The minimization (20) can be conducted by

$$
\frac{\partial G}{\partial \eta_{i, j}}=0 \quad i=1,2, \ldots, I ; j=1,2, \ldots, J ; I \times J=L
$$

Substitution of (25) into (26) leads to a set of $L$ linear algebraic equations with each equation having nine unknowns since the dynamic topography at the grid point $\eta_{i, j}$ is the corner point of four neighboring cells with $\left(\varepsilon_{i-1, j-1}\right.$, $\left.\varepsilon_{i, j-1}, \varepsilon_{i-1, j}, \varepsilon_{i, j}\right)$ evaluated at their centers and eight surrounding points $\left(\eta_{i-1, j-1}, \eta_{i, j-1}, \eta_{i+1, j-1}, \eta_{i-1, j}, \eta_{i+1, j}, \eta_{i-1, j+1}\right.$, $\eta_{i, j+1}, \eta_{i+1, j+1}$ ) (see Fig. 2),

$$
\begin{aligned}
& a_{i, j}^{11} \cdot \eta_{i-1, j-1}+a_{i, j}^{21} \cdot \eta_{i, j-1}+a_{i, j}^{31} \cdot \eta_{i+1, j-1} \\
+ & a_{i, j}^{12} \cdot \eta_{i-1, j}+a_{i, j}^{22} \cdot \eta_{i, j}+a_{i, j}^{32} \cdot \eta_{i+1, j}=s_{i, j} \\
+ & a_{i, j}^{13} \cdot \eta_{i-1, j+1}+a_{i, j}^{23} \cdot \eta_{i, j+1}+a_{i, j}^{33} \cdot \eta_{i+1, j+1}
\end{aligned}
$$

where

$$
\begin{aligned}
& a_{i, j}^{11}=-\frac{1}{4} A_{i-1, j-1} \cdot\left(\frac{\bar{f}_{i, j}}{f_{i-1, j-1}}\right)^{2} \cdot\left(\frac{1}{\Delta y_{i-1, j-1}^{2}}+\frac{1}{\Delta x_{i-1, j-1}^{2}}\right) \\
& a_{i, j}^{21}=\frac{1}{4} A_{i-1, j-1} \cdot\left(\frac{\bar{f}_{i, j}}{f_{i-1, j-1}}\right)^{2} \cdot\left(\frac{1}{\Delta x_{i-1, j-1}^{2}}-\frac{1}{\Delta y_{i-1, j-1}^{2}}\right)+\frac{1}{4} A_{i, j-1} \cdot\left(\frac{\bar{f}_{i, j}}{f_{i, j-1}}\right)^{2} \cdot\left(\frac{1}{\Delta x_{i, j-1}^{2}}-\frac{1}{\Delta y_{i, j-1}^{2}}\right) \\
& a_{i, j}^{31}=-\frac{1}{4} A_{i, j-1} \cdot\left(\frac{\bar{f}_{i, j}}{f_{i, j-1}}\right)^{2} \cdot\left(\frac{1}{\Delta y_{i, j-1}^{2}}+\frac{1}{\Delta x_{i, j-1}^{2}}\right) \\
& a_{i, j}^{12}=\frac{1}{4} A_{i-1, j-1} \cdot\left(\frac{\bar{f}_{i, j}}{f_{i-1, j-1}}\right)^{2} \cdot\left(\frac{1}{\Delta y_{i-1, j-1}^{2}}-\frac{1}{\Delta x_{i-1, j-1}^{2}}\right)+\frac{1}{4} A_{i-1, j} \cdot\left(\frac{\bar{f}_{i, j}}{f_{i-1, j}}\right)^{2} \cdot\left(\frac{1}{\Delta y_{i-1, j}^{2}}-\frac{1}{\Delta x_{i-1, j}^{2}}\right) \\
& a_{i, j}^{22}=\frac{1}{4} A_{i-1, j-1} \cdot\left(\frac{\bar{f}_{i, j}}{f_{i-1, j-1}}\right)^{2} \cdot\left(\frac{1}{\Delta x_{i-1, j-1}^{2}}+\frac{1}{\Delta y_{i-1, j-1}^{2}}\right)+\frac{1}{4} A_{i, j-1} \cdot\left(\frac{\bar{f}_{i, j}}{f_{i, j-1}}\right)^{2} \cdot\left(\frac{1}{\Delta x_{i, j-1}^{2}}+\frac{1}{\Delta y_{i, j-1}^{2}}\right) \\
& +\frac{1}{4} A_{i-1, j} \cdot\left(\frac{\bar{f}_{i, j}}{f_{i-1, j}}\right)^{2} \cdot\left(\frac{1}{\Delta x_{i-1, j}^{2}}+\frac{1}{\Delta y_{i-1, j}^{2}}\right)+\frac{1}{4} A_{i, j} \cdot\left(\frac{\bar{f}_{i, j}}{f_{i, j}}\right)^{2} \cdot\left(\frac{1}{\Delta x_{i, j}^{2}}+\frac{1}{\Delta y_{i, j}^{2}}\right) \\
& a_{i, j}^{32}=\frac{1}{4} A_{i, j-1} \cdot\left(\frac{\bar{f}_{i, j}}{f_{i, j-1}}\right)^{2} \cdot\left(\frac{1}{\Delta y_{i, j-1}^{2}}-\frac{1}{\Delta x_{i, j-1}^{2}}\right)+\frac{1}{4} A_{i, j} \cdot\left(\frac{\bar{f}_{i, j}}{f_{i, j}}\right)^{2} \cdot\left(\frac{1}{\Delta y_{i, j}^{2}}-\frac{1}{\Delta x_{i, j}^{2}}\right) \\
& a_{i, j}^{13}=-\frac{1}{4} A_{i-1, j} \cdot\left(\frac{\bar{f}_{i, j}}{f_{i-1, j}}\right)^{2} \cdot\left(\frac{1}{\Delta y_{i-1, j}^{2}}+\frac{1}{\Delta x_{i-1, j}^{2}}\right) \\
& a_{i, j}^{23}=\frac{1}{4} A_{i-1, j} \cdot\left(\frac{\bar{f}_{i, j}}{f_{i-1, j}}\right)^{2} \cdot\left(\frac{1}{\Delta x_{i-1, j}^{2}}-\frac{1}{\Delta y_{i-1, j}^{2}}\right)+\frac{1}{4} A_{i, j} \cdot\left(\frac{\bar{f}_{i, j}}{f_{i, j}}\right)^{2} \cdot\left(\frac{1}{\Delta x_{i, j}^{2}}-\frac{1}{\Delta y_{i, j}^{2}}\right) \\
& a_{i, j}^{33}=-\frac{1}{4} A_{i, j} \cdot\left(\frac{\bar{f}_{i, j}}{f_{i, j}}\right)^{2} \cdot\left(\frac{1}{\Delta y_{i, j}^{2}}+\frac{1}{\Delta x_{i, j}^{2}}\right) \\
& s_{i, j}=\frac{1}{2}\left(\frac{\bar{f}_{i, j}}{f_{i-1, j-1}}\right)^{2} \cdot\left(\frac{B_{i-1, j-1}}{\Delta y_{i-1, j-1}}-\frac{C_{i-1, j-1}}{\Delta x_{i-1, j-1}}\right)+\frac{1}{2}\left(\frac{\bar{f}_{i, j}}{f_{i, j-1}}\right)^{2} \cdot\left(\frac{B_{i, j-1}}{\Delta y_{i, j-1}}+\frac{C_{i, j-1}}{\Delta x_{i, j-1}}\right) \\
& -\frac{1}{2}\left(\frac{\bar{f}_{i, j}}{f_{i-1, j}}\right)^{2} \cdot\left(\frac{B_{i-1, j}}{\Delta y_{i-1, j}}+\frac{C_{i-1, j}}{\Delta x_{i-1, j}}\right)-\frac{1}{2}\left(\frac{\bar{f}_{i, j}}{f_{i, j}}\right)^{2} \cdot\left(\frac{B_{i, j}}{\Delta y_{i, j}}-\frac{C_{i, j}}{\Delta x_{i, j}}\right)
\end{aligned}
$$


The set of $L$ linear algebraic equations can be written in the matrix form,

$$
\mathbf{D \eta}=\mathbf{s}
$$

where $\mathbf{D}$ is the $L \times L$ coefficient matrix,

$$
\mathbf{D}=\left[\begin{array}{lllllllll}
d_{11} & d_{12} & \ldots & & & & & & \\
d_{21} & d_{22} & d_{23} & \ldots & & \ldots & & & \\
0 & d_{32} & d_{33} & d_{34} & \ldots & & & & \\
& & \ldots & \ldots & & & & & \\
& & & \ldots & \ldots & & & & \\
& & & & \ldots & \ldots & & & \\
& & & & \ldots & d_{L-2, L-3} & d_{L-2, L-2} & d_{L-2, L-1} & \\
& & & & & & d_{L-2, L-1} & d_{L-1, L-1} & d_{L-1, L} \\
& & & & & & & d_{L-1, L} & d_{L L}
\end{array}\right]
$$

with three stripes of nonzero diagonal elements except at the two end points $\left(x_{1,1}, y_{1,1}\right),\left(x_{I, J}, y_{I, J}\right)$, and nine nonzero elements in each row. The determinant of $D$ is usually nonzero.

$$
\boldsymbol{\eta}^{T}
$$
$\left(\eta_{1,1}, \eta_{1,2}, \ldots, \eta_{1, J}, \ldots, \eta_{2,1}, \eta_{2,2}, \ldots, \eta_{2, J}, \ldots, \eta_{I, 1}, \eta_{I, 2}, \ldots, \eta_{I, J}\right)$ is an $L$-dimensional vector for the dynamic topography; $\mathbf{s}^{T}=$ $\left(s_{1,1}, s_{1,2}, \ldots, s_{1, J}, \ldots, s_{2,1}, s_{2,2}, \ldots, s_{2, J}, \ldots, s_{I, 1}, s_{I, 2}, \ldots, s_{I, J}\right)$ is an $L$-dimensional vector for the constants. Here, the superscript $T$ means the transpose. Inverse of the coefficient matrix $\mathbf{D}$ leads to the solution,

$$
\boldsymbol{\eta}=\mathbf{D}^{-1} \mathbf{s} \text {. }
$$

The Alternating-Direction Implicit (ADI) method described in Appendix B can also be used to solve the linear equation (30).

\subsection{Treatment of Lateral Boundary}

Three-types of grid cells are defined for the region $R$ containing land (Figure 3): sea cell (with no land mass), land cell (with no water mass), and boundary cell (with land and water masses). The dynamic topography $(\eta)$ is set to zero for the land cells and for the land parts of the boundary cells; and calculated for the sea and boundary cells. The absolute geostrophic velocity is calculated only at the sea cells. For the boundary cells, it is reasonable to set

$$
B_{i, j}=C_{i, j}=0
$$

because the absolute geostrophic velocity is not calculated. Substitution of (33) into (24) gives

$$
\begin{aligned}
\varepsilon_{i, j}= & \frac{1}{8} A_{i, j}\left(\left(\frac{\eta_{i+1, j+1}-\eta_{i+1, j}+\eta_{i, j+1}-\eta_{i, j}}{\Delta y_{i, j}}\right)^{2}+\right. \\
& \left.+\left(\frac{\eta_{i+1, j+1}-\eta_{i, j+1}+\eta_{i+1, j}-\eta_{i, j}}{\Delta x_{i, j}}\right)^{2}\right),
\end{aligned}
$$

for the water part in the boundary cells.

\begin{tabular}{|c|c|c|c|c|c|c|c|c|c|}
\hline 0 & 0 & 0 & 0 & 0 & 0 & 0 & 0 & 0 & 0 \\
\hline 0 & 0 & 0 & 0 & 0 & 0 & 0 & 0 & 0 & 0 \\
\hline 0 & Land & 0 & 0 & 0 & 0 & 0 & 0 & 0 & 0 \\
\hline 0 & 0 & 0 & 0 & 0 & 0 & 0 & 0 & 0 & 0 \\
\hline 0 & 0 & 0 & 0 & 0 & 0 & 0 & 0 & 0 & 0 \\
\hline 0 & 0 & 0 & 0 & 0 & \multicolumn{2}{|c|}{$\mathrm{Sea}$} & 0 & 0 & 0 \\
\hline 0 & 0 & 0 & 0 & 0 & 0 & 0 & 0 & 0 & 0 \\
\hline 0 & 0 & 0 & 0 & 0 & 0 & 0 & 0 & 0 & 0 \\
\hline
\end{tabular}

Figure 3. Three types of grid cells: land, sea, and boundary cells

\subsection{Treatment of Islands}

Let the ocean domain $\Omega$ contain $N$ islands. Since the normal velocity along the boundary of island is zero, it is reasonable to assume that the dynamic topography for a given island- $n$ is a constant (no horizontal variability)

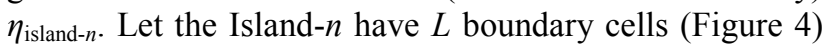
with the value of $\eta_{\text {island- } n}$. The dynamic topography at the sea cell grid point $\eta_{\text {island- } n}$ of the boundary cell is determined by the minimization (26), i.e.,

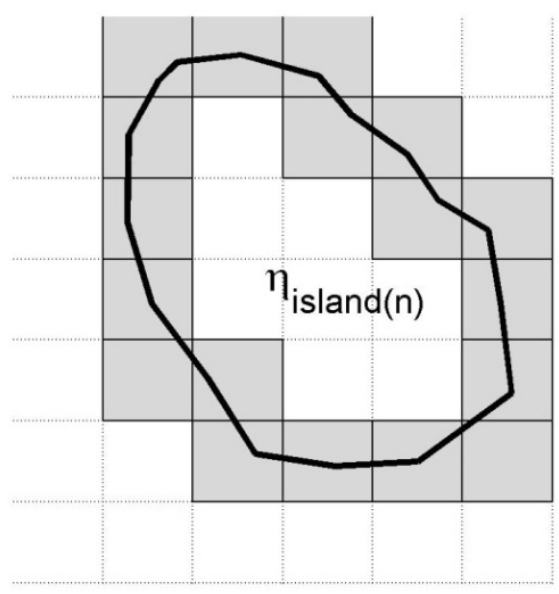

Figure 4. Treatment of island

$$
\frac{\partial G}{\partial \eta_{\text {island }-n}}=0, \quad n=1,2, \ldots, N \text {. }
$$

Substitution of (25) into (35) gives

$$
\eta_{\text {island }-n}=\sum_{i, j}^{\text {island }-n} \sum_{l, m=0}^{1} e_{l, m} \eta_{i+l, j+m},
$$

where $e_{l m}$ is the Kronecker delta,

$$
\begin{gathered}
e_{l m}=1, l=m \\
e_{l m}=0, \text { otherwise }
\end{gathered}
$$

and the grid $\left(x_{i+l, j+m}, \mathrm{y}_{i+l, j+m}\right)$ is in the land cell of the island- $n$. The dynamic topography $\eta_{\text {island- } n}$ depends on the island $-n$ coastline and neighboring grid points. 


\section{Example}

The example (North Atlantic Ocean) described below is only to show the technical aspects of the proposed method. It is not our intention to investigate/review the dynamics of the North Atlantic Ocean circulation, which has already been done by many authors for a long time period.

\subsection{Hydrographic Data}

The climatological annual mean $1^{\circ} \times 1^{\circ}(T, S)$ data for the North Atlantic Ocean $\left(100^{\circ} \mathrm{W}-6^{\circ} \mathrm{W}, 7^{\circ} \mathrm{N}-72^{\circ} \mathrm{N}\right)$ from the NOAA National Centers for Environmental Information (NCEI) World Ocean Atlas 2013 version 2 (WOA), downloaded at the website: http:/www.nodc.noaa.gov/OC5/woa13/woa13data.html, are used in this study to compute the dynamic topography $(\eta)$ and absolute geostrophic velocity $\left(u_{g}, v_{\mathrm{g}}\right)$. Figure 5 shows the temperature field at six different depths. At the sea surface, warm water $\left(>26^{\circ} \mathrm{C}\right)$ occupies the southwest part from the southern tip of Florida $\left(\sim 25^{\circ} \mathrm{N}\right)$ to the west coast of Africa $\left(\sim 12^{\circ} \mathrm{N}\right)$. The temperature reduces northward from $26^{\circ} \mathrm{C}$ to $6^{\circ} \mathrm{C}$ at $60^{\circ} \mathrm{N}$ east of Greenland $\left(\sim 45^{\circ} \mathrm{W}\right)$ and at $45^{\circ} \mathrm{N}$ near Newfoundland $\left(\sim 58^{\circ} \mathrm{W}\right)$. Strong thermal front, associated with the Gulf Stream, appears near the east coast of the North America from $24^{\circ} \mathrm{C}$ at around $30^{\circ} \mathrm{N}$ to $6^{\circ} \mathrm{C}$ at around $45^{\circ} \mathrm{N}$. At $100 \mathrm{~m}$ depth, comparing to the surface, the temperature pattern shows similarity especially the existence of the thermal front near the east coast of the North America from $20^{\circ} \mathrm{C}$ at around $30^{\circ} \mathrm{N}$ to $4^{\circ} \mathrm{C}$ at around $45^{\circ} \mathrm{N}$, and dissimilarity evidently the occurrence of a warm pool with a closed isothermal contour of $24^{\circ} \mathrm{C}$ occurs in the west tropics south of $30^{\circ} \mathrm{N}$. At $500 \mathrm{~m}$ depth, the thermal front weakens with reduced temperature difference from $16^{\circ} \mathrm{C}$ at around $30^{\circ} \mathrm{N}$ to $4^{\circ} \mathrm{C}$ at around $45^{\circ} \mathrm{N}$. The warm pool moves northward with a closed isothermal contour of $16^{\circ} \mathrm{C}$ in the western part near Florida. At $1000 \mathrm{~m}$ depth, the thermal front further weakens. Two warm pools occur with the west one located at almost the same place as at $500 \mathrm{~m}$ depth with a closed isothermal contour of $7^{\circ} \mathrm{C}$. The east one located west of African cost $\left(\sim 30^{\circ} \mathrm{N}-45^{\circ} \mathrm{N}\right)$ with a closed isothermal contour of $10^{\circ} \mathrm{C}$. At $3500 \mathrm{~m}$ and $4500 \mathrm{~m}$ depths, the temperature is quite uniform with $2.4-2.6^{\circ} \mathrm{C}$ at $3500 \mathrm{~m}$ depth, and $2.2-2.4^{\circ} \mathrm{C}$ at $4500 \mathrm{~m}$ depth.

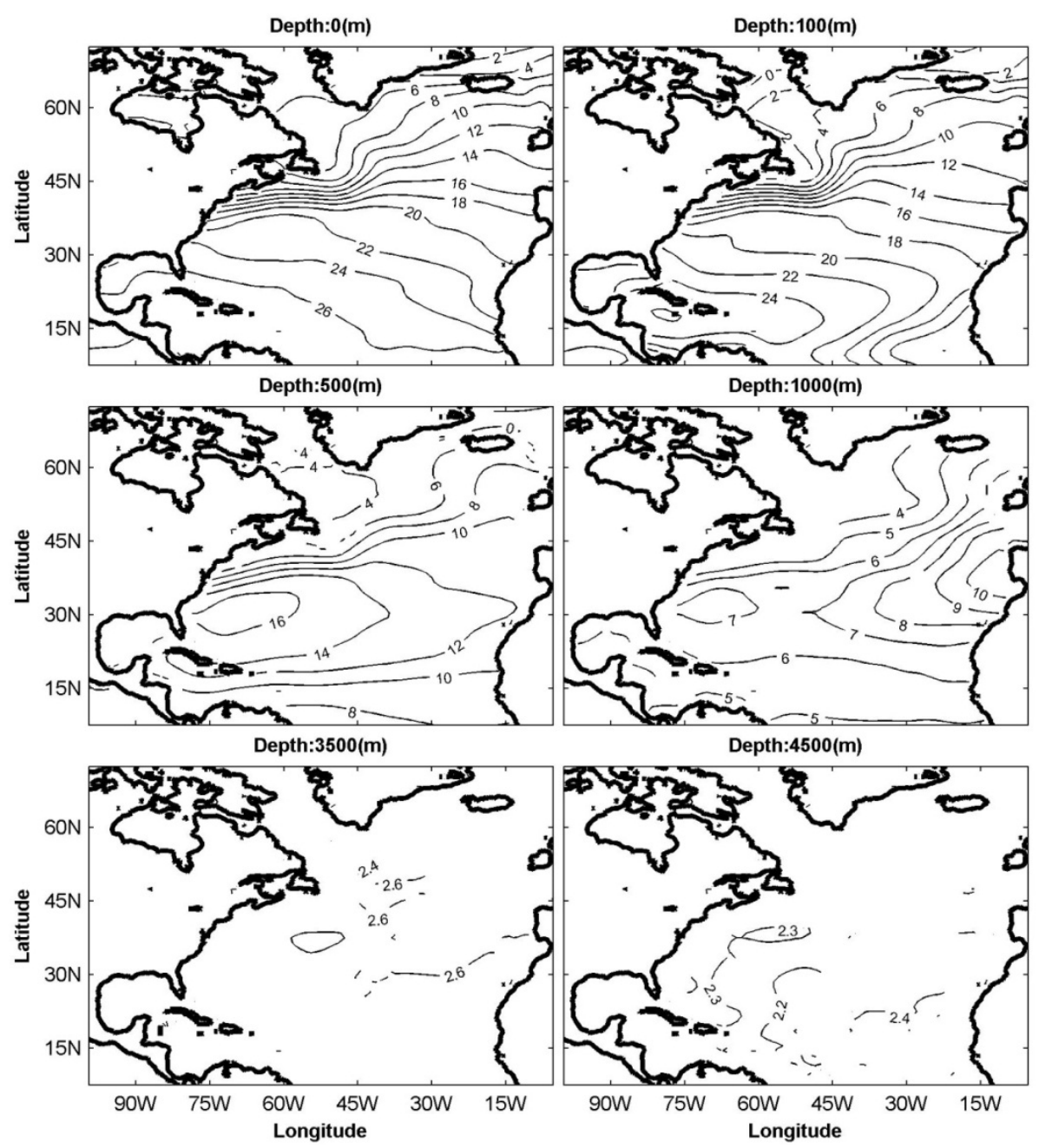

Figure 5. Climatological annual mean temperature in the North Atlantic Ocean from the WOA at various depths: (a) $\mathrm{z}=0$, (b) $100 \mathrm{~m}$, (c) $500 \mathrm{~m}$, (d) $1000 \mathrm{~m},(\mathrm{e}) 3500 \mathrm{~m}$, and (f) $4500 \mathrm{~m}$ 
Fig. 6 shows the salinity field at six different depths. At the sea surface, saltier region ( $>36.0 \mathrm{psu})$ occupies the vast region between $12^{\circ} \mathrm{N}-40^{\circ} \mathrm{N}$ with the salt pool $(>37 \mathrm{psu})$ occurring in the eastern part $\left(\sim 17^{\circ} \mathrm{N}-30^{\circ} \mathrm{N}, 25^{\circ} \mathrm{W}-60^{\circ} \mathrm{W}\right)$. A strong haline front appears along the North American coast from $30^{\circ} \mathrm{N}$ to $60^{\circ} \mathrm{N}$ with the salinity difference of $4 \mathrm{psu}(32$ to $36 \mathrm{psu}$ ) in the southern part (south of $45^{\circ} \mathrm{N}$ ) and of $2 \mathrm{psu}$ ( 32 to $34 \mathrm{psu}$ ) in the northern part (north of $45^{\circ} \mathrm{N}$ ). The isohaline contours with $1.0 \mathrm{psu}$ increment spread at around $\left(45^{\circ} \mathrm{N}, 45^{\circ} \mathrm{W}\right)$ with weak salinity gradient east of $45^{\circ} \mathrm{W}$. At $100 \mathrm{~m}$ depth ( $0.5 \mathrm{psu}$ contour interval), the salinity pattern is very similar to that at the surface. At $500 \mathrm{~m}$ depth $(0.2 \mathrm{psu}$ contour interval), the southern salt pool weakens $(>36.2$ psu) and westward shifts. The haline front still exists near the North American coast with reduced strength. At $1000 \mathrm{~m}$ depth, the haline front near the North American coast disappears. A salt pool occurs west of African $\operatorname{cost}\left(\sim 30^{\circ} \mathrm{N}\right.$ $-45^{\circ} \mathrm{N}$ ) with a closed haline contour of $36.0 \mathrm{psu}$. At $3500 \mathrm{~m}$ and $4500 \mathrm{~m}$ depths, the salinity is quite uniform with near $34.92 \mathrm{psu}$ at $3500 \mathrm{~m}$ depth, and $34.88-34.92$ at $4500 \mathrm{~m}$ depth.
The three dimensional density $\hat{\rho}_{i, j, k}$ is calculated from the WOA climatological annual mean temperature and salinity data $\left(T_{i, j, k}, \quad S_{i, j, k}\right)$ using the international thermodynamic equation of seawater -2010 , which is downloaded from the website: http://unesdoc.unesco.org/images/0018/001881/188170e.p df. The ocean depth data $H_{i, j}$ is downloaded from the NECI 5-Minute Gridded Global Relief Data Collection (ETOPO5) at the website: https://www.ngdc.noaa.gov/mgg/fliers/93mgg01.html.

The numerical calculation is conducted using the WOA grids $\left(1^{\circ} \times 1^{\circ}\right)$,

$$
\Delta x_{i, j}=\Delta x_{j}=\frac{\pi \cos \phi}{360} \mathrm{r}_{E}, \Delta y_{i, j}=\Delta y=\frac{\pi}{360} \mathrm{r}_{E},
$$

where $\phi$ is the latitude; $\mathrm{r}_{E}=6,371 \mathrm{~km}$, is the earth radius, $i=$ $1,2, \ldots, 95 ; j=1,2, \ldots, 66$ (i.e., $I=95, J=66$ ). The parameters $\left(A_{i, j}, B_{i, j}, C_{i, j}\right)$ from the data using (A3)-(A5). Then, the elements of the coefficient matrix $\mathbf{D}$ and the constant vector $\mathbf{s}$ are calculated from the values of $\left(A_{i, j}, B_{i, j}\right.$, $C_{i, j}$ ) using (28) and (29), respectively. Use of (32) gives the dynamic topography vector $\boldsymbol{\eta}$ [or field $\eta\left(x_{i}, y_{j}\right)$ ].

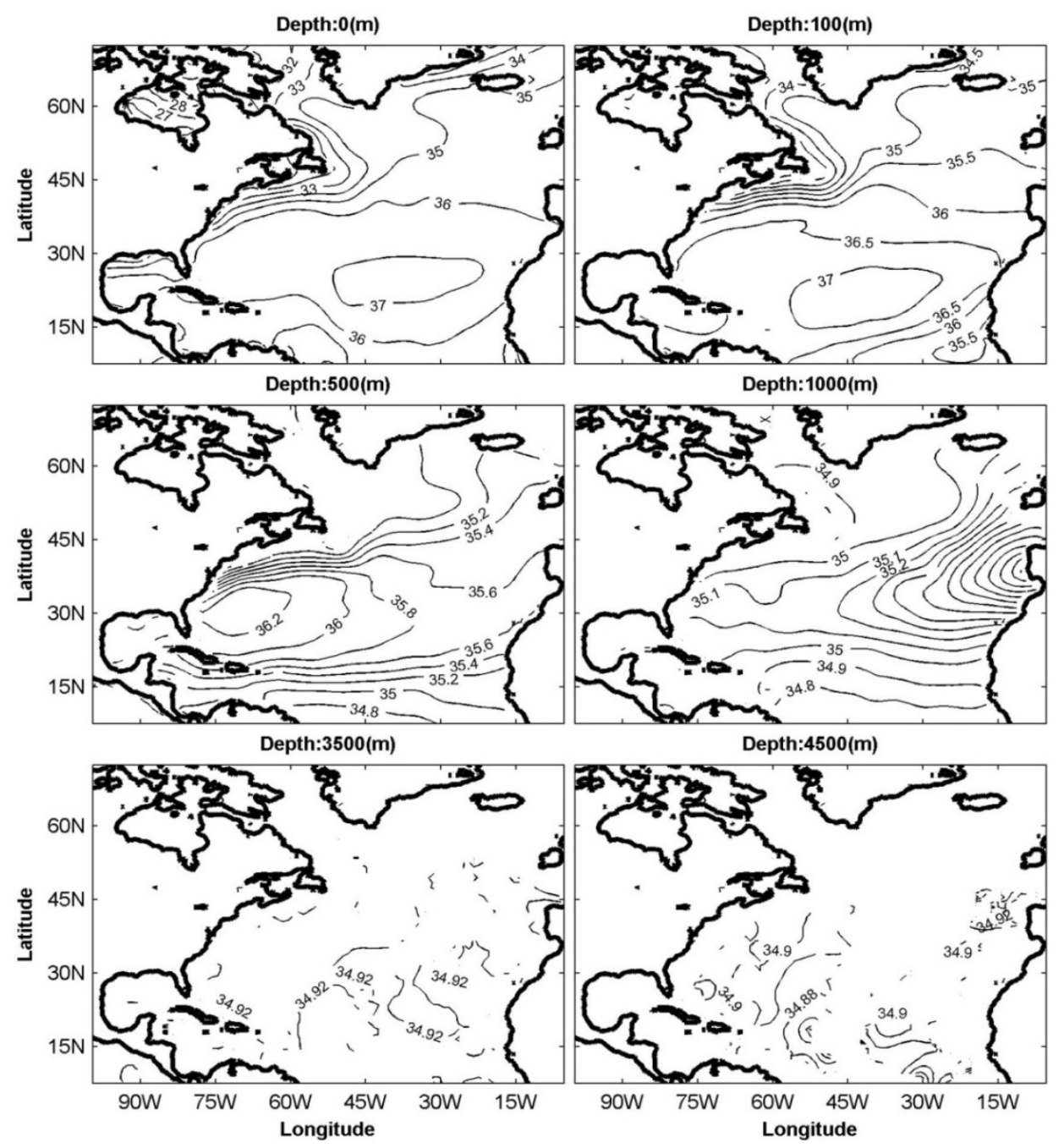

Figure 6. Climatological annual mean salinity (psu) in the North Atlantic Ocean from the WOA at various depths: (a) $0 \mathrm{~m}$, (b) $100 \mathrm{~m}$, (c) $500 \mathrm{~m}$, (d) $1000 \mathrm{~m}$, (e) $3500 \mathrm{~m}$, and (f) $4500 \mathrm{~m}$ 

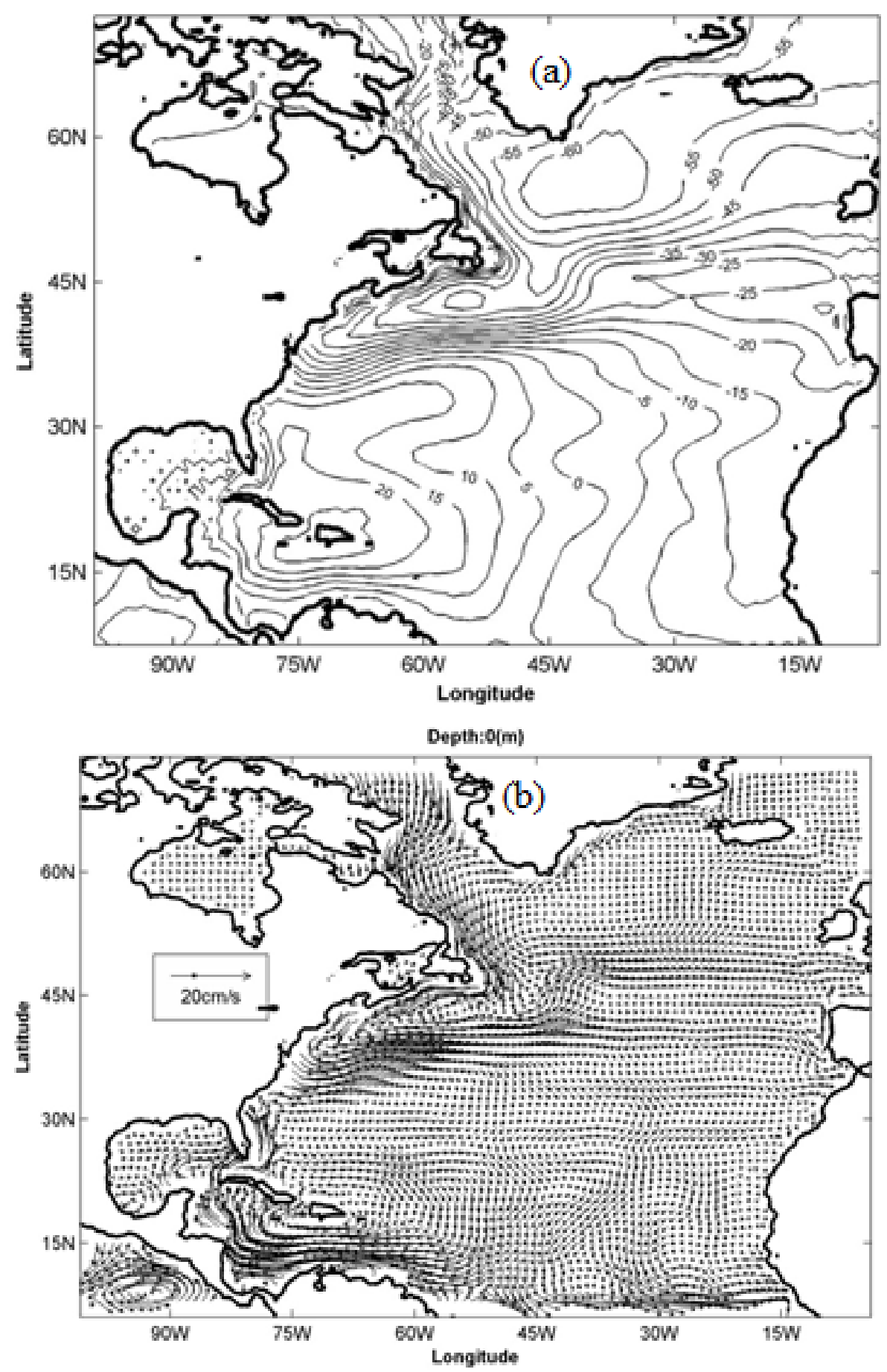

Figure 7. Climatological annual mean (a) sea level $\eta(\mathrm{cm})$, and (b) surface geostrophic velocity vectors calculated from the WOA (T, S) data using the MES method.

\subsection{Dynamic Topography and Absolute Geostrophic Velocity}

The inverted dynamic topography $\eta$ (Figure 7a) and associated surface geostrophic velocity vectors (Figure $7 \mathrm{~b}$ ) clearly show the double-gyre structure: high dynamic topography region (with a maximum of $29 \mathrm{~cm}$ near Hatti) associated with the North Atlantic Gyre (anticyclonic, south of $46^{\circ} \mathrm{N}$ ) and low dynamic topography region (with a minimum value of $-63 \mathrm{~cm}$ southeast of Greenland) associated with the North Atlantic Subpolar Gyre (cyclonic, north of $46^{\circ} \mathrm{N}$ ). The flow patterns of the inverted surface geostrophic velocity (Figure 7b) coincide with the observed surface ocean currents with weaker speeds since the geostrophic velocity does not include wind driven ocean currents.

The characteristics of the surface geostrophic velocity from Figure $7 \mathrm{~b}$ are outlined as follows. The North Atlantic 
Gyre includes westward north equatorial currents (evident west of $45^{\circ} \mathrm{W}$ ), and its branches, Antilles Current, Florida Current, and Gulf Stream with the maximum speed near 20 $\mathrm{cm} \mathrm{s}^{-1}$ (smaller than observed maximum current speed). The Antilles Current flows northward east of Antilles (near $15^{\circ} \mathrm{N}, 60^{\circ} \mathrm{W}$ ) and joins the Florida Current near Bahamas (near $25^{\circ} \mathrm{N}, 77^{\circ} \mathrm{W}$ ). The Gulf Stream (extensive western boundary current) begins upstream of Cape Hatteras (near $35^{\circ} \mathrm{N}, 75^{\circ} \mathrm{W}$ ), flows northeastward along the east coast, leaves the coast at around $38^{\circ} \mathrm{N}$, moves eastward, and joins the North Atlantic Current at $60^{\circ} \mathrm{W}$. The eastward moving North Atlantic Current is split into two branches at around $45^{\circ} \mathrm{W}$. The weaker branch flows eastward and reaches the west coast of North Africa. The stronger branch flows northeastward and becomes the southeast portion of the cyclonic North Atlantic Subpolar Gyre, spanning $45^{\circ} \mathrm{N}$ to $65^{\circ} \mathrm{N}$. Besides the North Atlantic Currents, Figure $7 \mathrm{~b}$ also shows five other major currents associated with the North Atlantic Subpolar Gyre: the Irminger Current splitting from the North Atlantic Current near $\left(50^{\circ} \mathrm{N}, 30^{\circ} \mathrm{W}\right)$, the narrow East Greenland Current flowing southwestward and weak West Greenland Current moving northwestward along the southern Greenland coast, the strong wide Baffin Island Current flowing southward from $75^{\circ} \mathrm{N}$ to $60^{\circ} \mathrm{N}$ along the Baffin Island, and the Labrador Current (continuation of the Baffin Island Current and the West Greenland Current) flowing southeastward from $60^{\circ} \mathrm{N}$ to $45^{\circ} \mathrm{N}$ and then southwestward along the east coasts of Labrador
Island and North America, and joining the Gulf Stream near $\left(38^{\circ} \mathrm{N}, 75^{\circ} \mathrm{W}\right)$.

The absolute geostrophic velocity vectors at $500 \mathrm{~m}$ depth (Figure $8 \mathrm{a}$ ) are quite similar to the surface geostrophic velocity (Figure $7 \mathrm{~b}$ ) with reduced intensity. The maximum speed is around $10 \mathrm{~cm} \mathrm{~s}^{-1}$ (in the Gulf Stream) and the North Atlantic Subtropical Gyre shrinks in its north-south extension with increasing depth from the surface to $500 \mathrm{~m}$ depth, which agrees with Olbers et al. (1985) and Chu (1995). The flow patterns at deeper ocean $(1000 \mathrm{~m}, 3500 \mathrm{~m}$, and $4500 \mathrm{~m}$ ) are shown in Figure $8 \mathrm{~b}, 8 \mathrm{c}, 8 \mathrm{~d}$. The dominant feature at $1000 \mathrm{~m}$ depth is the existence of southward flowing western boundary current along the east coast of North America and associated cyclonic gyre in the Sargasso Sea. This gyre is noticeable at deep depths $(3500 \mathrm{~m}, 4500 \mathrm{~m})$ with a maximum swirl speed around $2 \mathrm{~cm}$ $\mathrm{s}^{-1}$. An evident southeastward flow $\left(\sim 2 \mathrm{~cm} \mathrm{~s}^{-1}\right)$ is identified near Bahamas (south of $20^{\circ} \mathrm{N}, 60^{\circ} \mathrm{W}-50^{\circ} \mathrm{W}$ ) carrying water into the South Atlantic Ocean. Same as with the P vector method [5] (Chu 1995), a cyclonic-anticyclonic pair is also found in the deep water at the eastern $\left(20^{\circ} \mathrm{W}-40^{\circ} \mathrm{W}\right)$ tropical $\left(10^{\circ} \mathrm{N}-30^{\circ} \mathrm{N}\right)$ North Atlantic Ocean. The cyclonic eddy is in the south, and the anticyclonic eddy is in the north. The maximum swirl speed is around $2 \mathrm{~cm} \mathrm{~s}^{-1}$. This feature is indeed strikingly similar to the map [14] of the absolute flow at $2000 \mathrm{~m}$ depth (reproduced in [15]). Furthermore, our computation shows that this di-pole structure becomes more evident as the depth increases.

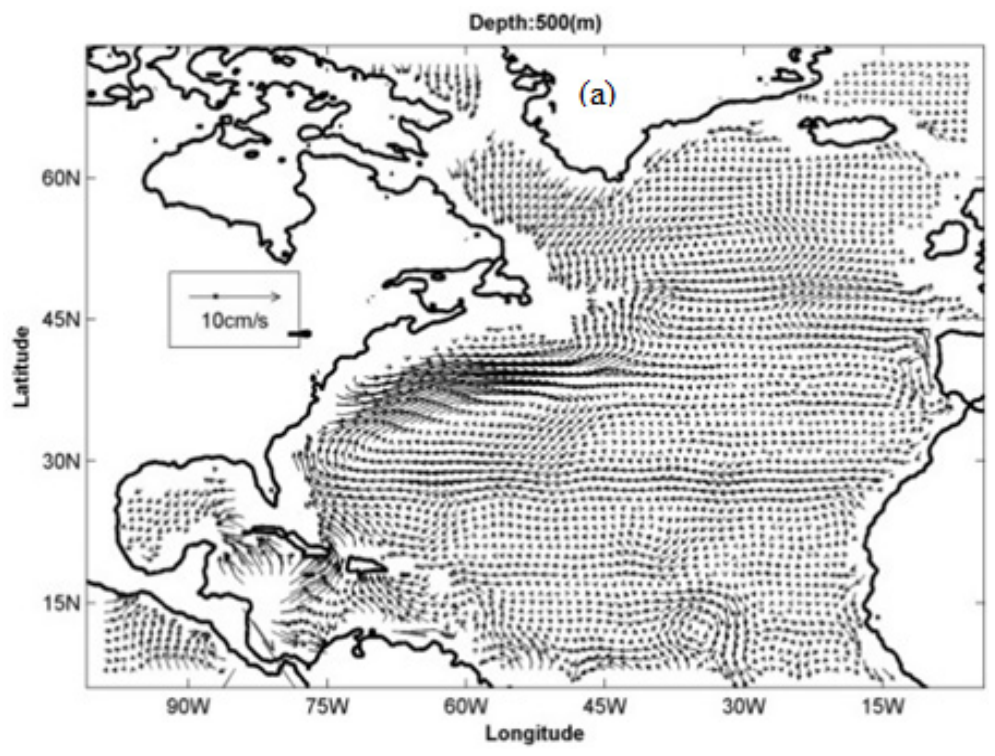



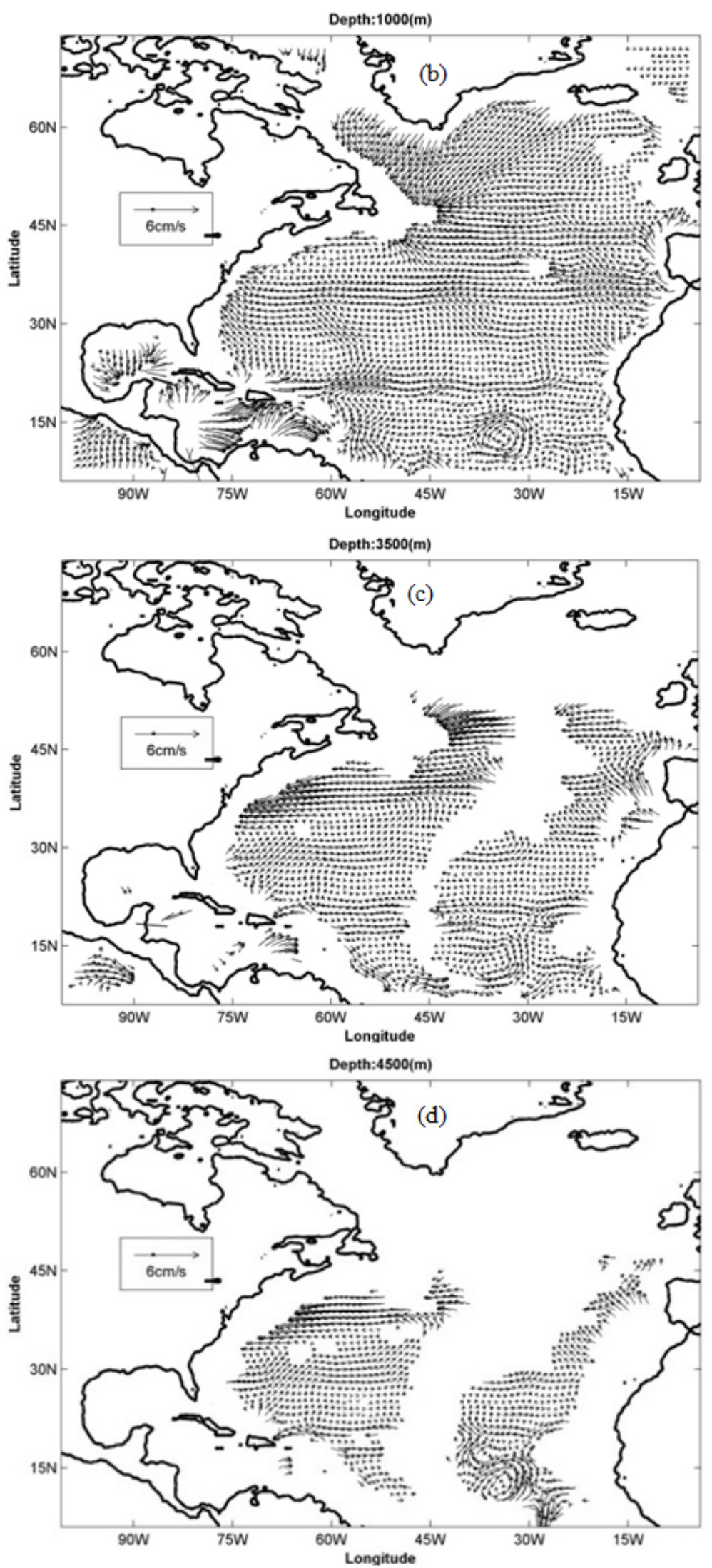

Figure 8. Inverted annual mean absolute geostrophic velocity vectors calculated from the WOA (T, S) data using the MES method at various depths: (a) $500 \mathrm{~m}$, (b) $2500 \mathrm{~m}$, (c) $3500 \mathrm{~m}$, and (d) $4500 \mathrm{~m}$ 
The vertical cross-section of the zonal absolute geostrophic velocity component at $57^{\circ} \mathrm{W}$ (Figure 9) shows the similar features identified using the box model [11] [16], the $\beta$ spiral method [1], and the P-vector method [5]: (a) a strong upper ocean (above $1000 \mathrm{~m}$ depth) eastward flow between $30^{\circ} \mathrm{N}-42^{\circ} \mathrm{N}$ with a maximum speed around $12 \mathrm{~cm} \mathrm{~s}^{-1}$, (b) a weak westward flow $\left(\sim 2 \mathrm{~cm} \mathrm{~s}^{-1}\right)$ in deep layer below $3000 \mathrm{~m}$, (c) a near surface westward flow south of $30^{\circ} \mathrm{N}$ (southern branch of the North Atlantic Gyre) with a maximum speed of $5 \mathrm{~cm} \mathrm{~s}^{-1}$, and (d) banded structure in the deep layers $(\mathrm{z}<1500 \mathrm{~m})$, where the current direction alternates on a horizontal scale around $2000 \mathrm{~km}$, which is wider than the results reported in [16].

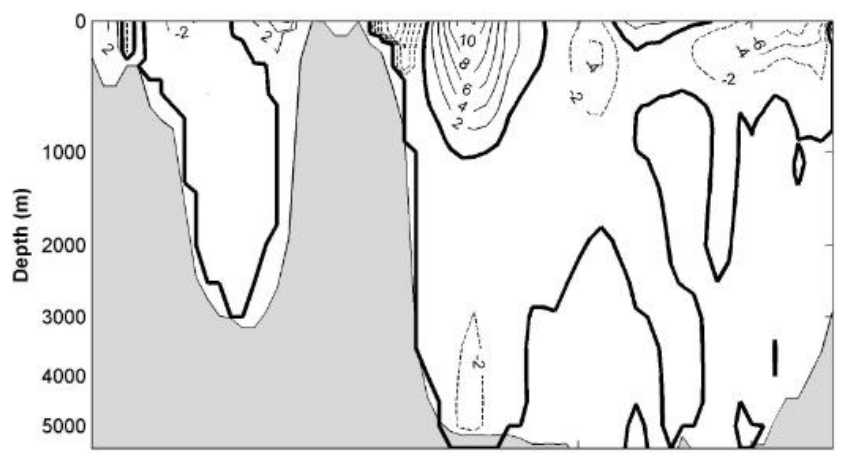

Figure 9. Vertical cross section of zonal absolute geostrophic velocity (unit: $\mathrm{cm} \mathrm{s}^{-1}$ ) at $57^{\circ} \mathrm{W}$

\section{Conclusions}

On the theoretical base of minimum energy state of the geostrophic velocity with given potential vorticity, a straightforward MES method is proposed to determine the dynamic topography $(\eta)$ and in turn the absolute geostrophic velocity from hydrographic data. This leads to a new mathematical problem how to find $\eta$ to minimize the functional $G\left(\eta_{x}, \eta_{y}\right)$. In numerical approach, a set of corresponding linear algebraic equations is derived and solved to get $\eta$ at grid points.

Identification of $\eta$ has several advantages in comparison to the existing methods that determine the velocity $\left(u_{r e f}, v_{r e f}\right)$ at a reference level. First, number of unknown variables reduces from 2 [i.e., $\left(u_{r e f}, v_{r e f}\right)$ ] to 1 [i.e., $\eta$ ]. Second, the geostrophic velocity is usually an order larger at the surface than at a deep reference level. Noise in $(T, S)$ data has relatively larger impact on the deep reference-level velocity than on the surface geostrophic velocity. Third, the geostrophy is guaranteed for all the inverted three-dimensional absolute velocity using the MES method, but is not always guaranteed using the existing methods since it is difficult to prove that the reference velocity $\left(u_{r e f}\right.$, $\left.v_{\text {ref }}\right)$ is geostrophic balanced.

The climatological annual mean dynamic topography $\eta$ for the North Atlantic Ocean $\left(100^{\circ} \mathrm{W}-6^{\circ} \mathrm{W}, 7^{\circ} \mathrm{N}-72^{\circ} \mathrm{N}\right)$ on $1^{\circ} \times 1^{\circ}$ grids is obtained from the three dimensional $(T, S)$ data of the NOAA National Centers for Environmental Information (NCEI) World Ocean Atlas 2013 version 2. The inverted $\eta$ agrees with early studies especially the double-gyre structure with an anticyclonic North Atlantic Gyre south of $46^{\circ} \mathrm{N}$, and a cyclonic North Atlantic Subpolar Gyre north of $46^{\circ} \mathrm{N}$. The three dimensional structure of the inverted absolute geostrophic velocity fits the classical view of the North Atlantic circulation.

\section{Acknowledgements}

The author would like to thank Dr. Charles Sun for the GTSPP dataset and to thank Mr. Chenwu Fan for his outstanding efforts on the computation and graphics.

\section{Appendix A. Discretized Functional $G$}

The horizontal gradients $\left(\eta_{x}\right)_{i, j}$ and $\left(\eta_{y}\right)_{i, j}$ in the functional $G(24)$ are the averaged values of the two forward differences,

$$
\left(\frac{\partial \eta}{\partial x}\right)_{i, j}=\frac{\eta_{i+1, j}-\eta_{i, j}+\eta_{i+1, j+1}-\eta_{i, j+1}}{2 \Delta x_{i, j}},\left(\frac{\partial \eta}{\partial y}\right)_{i, j}=\frac{\eta_{i, j+1}-\eta_{i, j}+\eta_{i+1, j+1}-\eta_{i+1, j}}{2 \Delta y_{i, j}} .
$$

Substitution of (A1) into (24) gives,

$$
\begin{aligned}
& \varepsilon_{i, j}=\frac{A_{i, j}}{4 f_{i, j}^{2}}\left[\left(\frac{\eta_{i+1, j+1}-\eta_{i+1, j}+\eta_{i, j+1}-\eta_{i, j}}{\Delta y_{i, j}}\right)^{2}+\left(\frac{\eta_{i+1, j+1}-\eta_{i, j+1}+\eta_{i+1, j}-\eta_{i, j}}{\Delta x_{i, j}}\right)^{2}\right] \\
& -\frac{B_{i, j}}{f_{i, j}^{2}}\left(\frac{\eta_{i+1, j+1}-\eta_{i+1, j}+\eta_{i, j+1}-\eta_{i, j}}{\Delta y_{i, j}}\right)+\frac{C_{i, j}}{f_{i, j}^{2}}\left(\frac{\eta_{i+1, j+1}-\eta_{i, j+1}+\eta_{i+1, j}-\eta_{i, j}}{\Delta x_{i, j}}\right)
\end{aligned}
$$

where the parameters $\left(A_{i, j}, B_{i, j}, C_{i, j}\right)$ are calculated from the water depth $\left(H_{i, j}\right)$ and density $\left(\hat{\rho}_{i, j, k}\right)$ data,

$$
A_{i, j} \equiv \sum_{k=1}^{K_{i, j}} H_{i, j} \Delta x_{i, j} \Delta y_{i, j},
$$




$$
\begin{aligned}
& B_{i, j} \equiv \frac{\Delta x_{i, j} \Delta y_{i, j} \Delta z_{k}}{4 \rho_{0}} \sum_{k=2}^{K_{i, j}} \sum_{l=1}^{k}\left[\left(\begin{array}{l}
\frac{\hat{\rho}_{i, j+1, l}-\hat{\rho}_{i, j, l}}{\Delta y_{i, j}}+\frac{\hat{\rho}_{i+1, j+1, l}-\hat{\rho}_{i+1, j, l}}{\Delta y_{i, j}} \\
+\frac{\hat{\rho}_{i, j+1, l+1}-\hat{\rho}_{i, j, l+1}}{\Delta y_{i, j}}+\frac{\hat{\rho}_{i+1, j+1, l+1}-\hat{\rho}_{i+1, j, l+1}}{\Delta y_{i, j}}
\end{array}\right)\left(\frac{d z_{l}+d z_{l+1}}{2}\right)\right]
\end{aligned}
$$

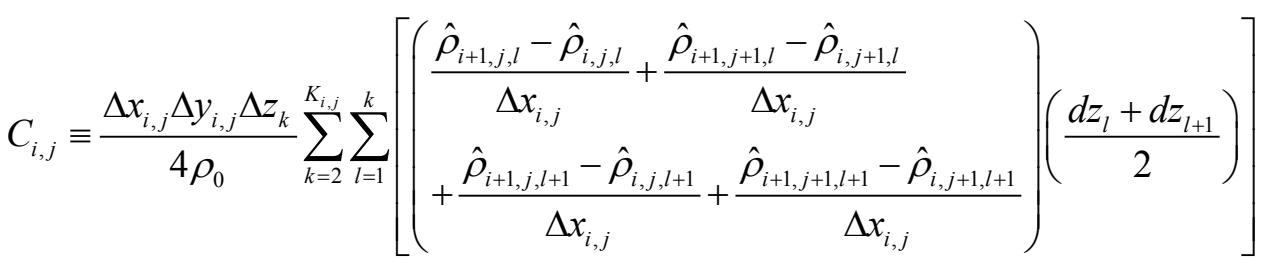

Substitution of (A2) into (24) leads to the numerical representation of the functional $G$,

$$
G=G\left(\eta_{1,1}, \eta_{1,2}, \ldots, \eta_{1, J}, \ldots, \eta_{2,1}, \eta_{2,2}, \ldots, \eta_{2, J}, \ldots, \eta_{I, 1}, \eta_{I, 2}, \ldots, \eta_{I, J}\right)
$$

\section{Appendix B. Alternating-Direction Implicit Method}

The Alternating-Direction Implicit (ADI) Method can be used to solve the set of algebraic equations (30) with large value of $I \times J$. The iteration starts from

$$
\eta_{i, j}^{(0)}=0, \quad i=1,2, \ldots, I ; j=1,2, \ldots, J
$$

which is taken as the state for the 0 -step. From steps $n$ to $n+1$, the iteration is divided into two parts: solving the $x$-direction implicit equations

$$
\begin{aligned}
& a_{i, j}^{12} \eta_{i-1, j}^{(n+1)}+a_{i, j}^{22} \eta_{i, j}^{(n+1)}+a_{i, j}^{32} \eta_{i+1, j}^{(n+1)}=s_{i, j}-a_{i, j}^{11} \eta_{i-1, j-1}^{(n)}-a_{i, j}^{21} \eta_{i, j-1}^{(n)}-a_{i, j}^{31} \eta_{i+1, j-1}^{(n)} \\
& -a_{i, j}^{13} \eta_{i-1, j+1}^{(n)}-a_{i, j}^{23} \eta_{i, j+1}^{(n)}-a_{i, j}^{33} \eta_{i+1, j+1}^{(n)},
\end{aligned}
$$

from $j=1$ to $j=J$, and solving the $y$-direction implicit equations

$$
\begin{aligned}
& a_{i, j}^{21} \eta_{i, j-1}^{(n+1)}+a_{i, j}^{22} \eta_{i, j}^{(n+1)}+a_{i, j}^{23} \eta_{i, j+1}^{(n+1)}=s_{i, j}-a_{i, j}^{11} \eta_{i-1, j-1}^{(n)}-a_{i, j}^{12} \eta_{i-1, j}^{(n)}-a_{i, j}^{13} \eta_{i-1, j+1}^{(n)} \\
& -a_{i, j}^{31} \eta_{i+1, j-1}^{(n)}-a_{i, j}^{32} \eta_{i+1, j}^{(n)}-a_{i, j}^{33} \eta_{i+1, j+1}^{(n)},
\end{aligned}
$$

from $i=1$ to $i=I$. Such iteration continues until the solutions are convergence.

\section{REFERENCES}

[1] Olbers, D.J., M. Wenzel, and J. Willebrand, 1985: The influence of North Atlantic circulation patterns from climatological hydrographic data. Reviews of Geophysics, 23, 313-356.

[2] Stommel, H., and F. Schott, 1977: The beta spiral and the determination of the absolute velocity field from hydrographic station data. Deep Sea Research, 24, 325-329.

[3] Stommel, H., P. Niller, and D. Anati, 1978: Dynamic topography and recirculation of the North Atlantic. Journal of Marine Research, 36, 449-468.

[4] Killworth, P.D., 1986: A Bernoulli inverse method for determining the ocean circulation. Journal of Physical Oceanography, 16, 2031-2051.

[5] Chu, P.C., 1995: P-vector method for determining absolute velocity from hydrographic data. Marine Technical Society Journal, 29 (3), 3-14.

[6] Chu, P.C., 2000: P-vector spirals and determination of absolute velocities. Journal of Oceanography, 56, 591-599.

[7] Chu, P.C., 2006: P-vector Inverse Method. Springer, 605pp.

[8] Chu, P.C., C.W. Fan, C.J. Lozano, and J. Kerling, 1998: An AXBT survey of the South China Sea. Journal of Geophysical Research, 103, 21637-21652.

[9] Chu, P.C., and R.F. Li, 2000: South China Sea isopycnal surface circulations. Journal of Physical Oceanography, 30, 2419-2438.

[10] Chu, P.C., R.F. Li, and X.B. You, 2002: Northwest Pacific subtropical countercurrent on isopycnal surface in summer. Geophysical Research Letters, 29, 10.1029/2002GLO14831.

[11] Wunsch, C., 1978: The general circulation of the North Atlantic west of $50^{\circ} \mathrm{W}$ determined from inverse method. Reviews of Geophysics, 16, 583-620. 
[12] Wunsch, C., 1996: The ocean circulation inverse problem. Cambridge Univ. Press, Cambridge, UK, 442pp.

[13] Davis, R., 1978: On estimating velocity from hydrographic data. Journal of Geophysical Research, 83, 5507-5509.

[14] Defant, A., 1941: Die absolute Topographie des physikalischen Meeresniveaus und der Dru"ckflachen sowie die Wasserbewegungen im Raum des Atlantischen Ozeans. In: Wissenschaftliche Ergebnisse der Deutschen Atlantischen Expedition auf dem Forschungs-und Vermessungsschiff "Meteor" 1925-27, vol. 6, second part,
1, Berlin, pp. 191-260.

[15] Reid, J. L., 1981: On the mid-depth circulation of the world ocean. In: Evolution in Physical Oceanography. Edited by B. Warren and C. Wunsch. MIT Press, 70-111.

[16] Wunsch, C. and B. Grant, 1982: Towards the general circulation of the North Atlantic Ocean. Progress in Oceanography, 11, 1-59. 